\title{
FEATHER MEAL AND RICE HUSK ENHANCED KERATINASES PRODUCTION BY BACILLUS LICHENIFORMIS YJ4 AND CHARACTERS OF PRODUCED KERATINASES
}

Hsin-Hung Lin

Nugen Bioscience (Taiwan) Co, Ltd. No. 29, 40th Rd., Taichung Industrial Park, Taichung 40768, Taiwan, R.O.C

Li-Jung Yin

Department of Seafood Science, National Kaohsiung Marine University, No. 142 Hai-Chuan Rd. Nan-Tzu, Kaohsiung 81143, Taiwan, R.O.C, ljyin@mail.nkmu.edu.tw

Follow this and additional works at: https://jmstt.ntou.edu.tw/journal

Part of the Life Sciences Commons

\section{Recommended Citation}

Lin, Hsin-Hung and Yin, Li-Jung (2010) "FEATHER MEAL AND RICE HUSK ENHANCED KERATINASES PRODUCTION BY BACILLUS LICHENIFORMIS YJ4 AND CHARACTERS OF PRODUCED KERATINASES," Journal of Marine Science and Technology. Vol. 18: Iss. 3, Article 18.

DOI: $10.51400 / 2709-6998.1894$

Available at: https://jmstt.ntou.edu.tw/journal/vol18/iss3/18

This Research Article is brought to you for free and open access by Journal of Marine Science and Technology. It has been accepted for inclusion in Journal of Marine Science and Technology by an authorized editor of Journal of Marine Science and Technology. 


\title{
FEATHER MEAL AND RICE HUSK ENHANCED KERATINASES PRODUCTION BY BACILLUS LICHENIFORMIS YJ4 AND CHARACTERS OF PRODUCED KERATINASES
}

\author{
Hsin-Hung Lin* and Li-Jung Yin**
}

Key words: Bacillus licheniformis, feather, rice husk, keratinase, character.

\begin{abstract}
A feather-degrading bacterium with high keratinase activity was isolated and identified as Bacillus licheniformis YJ4. After $72 \mathrm{~h}$ incubation in a medium $(0.5 \%$ feather meal, $0.05 \%$ $\mathrm{NH}_{4} \mathrm{Cl}$ and $\mathrm{NaCl}, 0.04 \% \mathrm{~K}_{2} \mathrm{HPO}_{4}, 0.03 \% \mathrm{KH}_{2} \mathrm{PO}_{4}, 0.01 \%$ $\mathrm{MgCl}_{2}$ and yeast extract, $0.1 \%$ rice husk) at $37^{\circ} \mathrm{C}, 2$ keratinases (keratinase I and II) were purified to electrophoretical homogeneity by CM sepharose and Sephadex G-75 chromatographs. They were with molecular masses $(M)$ of 35.5 and $32.8 \mathrm{kDa}$, isoelectric point $(\mathrm{p} I)$ of 6.63 and 6.50 , respectively, and stable at $\mathrm{pH} 6.0-10.0$ and $10-50^{\circ} \mathrm{C}$. The optimal $\mathrm{pH}$ and temperature were similar, at 9.0 and $60^{\circ} \mathrm{C}$, respectively. According to the effect of metal, inhibitor and reducing agent, and previous studies, the purified keratinases I and II were considered to be cysteine and serine proteases, respectively.
\end{abstract}

\section{INTRODUCTION}

Keratin, major component of feathers, is rich in disulfide bonds and also very stable and highly resistant to proteolysis by pepsin, trypsin, papain, etc. [10]. Currently, most of feathers from poultry industry are processed into feather meals by using high pressure and temperature. These dramatic conditions are time-consuming and high cost, and usually lower the nutritional value [26]. Because of being able to hydrolyze insoluble keratin substrate, the bacterial proteases has attracted many scientists and been well studied on the hydrolysis of hair and feather keratins [27].

Williams et al. [28] isolated a feather-degrading bacterium,

Paper submitted 04/13/09; revised 07/10/09; 11/20/09; accepted 01/04/10. Author for correspondence: Li-Jung Yin (e-mail: ljyin@mail.nkmu.edu.tw).

*Nugen Bioscience (Taiwan) Co, Ltd. No. 29, 40th Rd., Taichung Industrial Park, Taichung 40768, Taiwan, R.O.C.

**Department of Seafood Science, National Kaohsiung Marine University, No. 142 Hai-Chuan Rd. Nan-Tzu, Kaohsiung 81143, Taiwan, R.O.C.
Bacillus licheniformis PWD-1. According to their experiments on chicken, those fed by biodegraded feathers had better growth than those fed by untreated one or commercial feather diet [27, 28]. According to Williams et al. [27], the hydrolyzed feathers are still used as part of nitrogen source for animal feed, even though their high cost in the production of keratinase. Some other studies further indicated that keratin hydrolysates were also good organic fertilizers, materials for edible film processings and limited amino acids supplement for health foods and pet foods [10].

Poultry industry produces a large quantity of by product, feather, each year and greatly impacts our environment [27]. Economical production of keratinases and simplified feather proteolysis are, accordingly, of necessity for poultry industry [19]. Accordingly, recycling these feathers has long been concerned by many scientists and governments worldwide. Keratinases are considered to be able to proteolyze feather and can be produced by many microorganisms such as bacteria, actinomyces and fungi [10]. This study aimed to isolate the keratinase-producing bacterium, and further optimize the cultivation medium. Keratinases produced by isolated strain were also purified and characterized.

\section{MATERIALS AND METHODS}

\section{Materials}

Feather meal (100 meshes) from Arbor Acres Chicken and rice husk were pre-treated and kindly provided from Charoen Pokphand Enterprise (Indonesia) Co., LTD. All media for bacteria cultivation were from Difco Laboratories (BD Co., MD, USA). Azokeratin was prepared in our laboratory according to Riffel et al. [19]. All metals, inhibitors and reducing agents were the products of Sigma-Aldrich Inc. (St. Louis, MO, USA).

\section{Screening of Keratinase-Producing Bacteria}

The feather degrading bacterium was screened from decomposed chicken feathers from a local poultry slaughter house in southern Taiwan. Ten \% of sample suspended in sterile phosphate buffered saline (PBS, $10 \mathrm{mM}$ potassium 
phosphate buffer, $150 \mathrm{mM} \mathrm{NaCl}$, pH 7.4) was inoculated and incubated in a $1.0 \%$ feather meal broth $(\mathrm{pH} 7.5)$ at $37^{\circ} \mathrm{C}$ for 7 days. To a medium (feather meal broth, FMB) containing $1.0 \%$ feather meal, $0.05 \%$ of $\mathrm{NH}_{4} \mathrm{Cl}$ and $\mathrm{NaCl}, 0.04 \% \mathrm{~K}_{2} \mathrm{HPO}_{4}$, $0.03 \% \mathrm{KH}_{2} \mathrm{PO}_{4}, 0.01 \%$ of $\mathrm{MgCl}_{2}$ and yeast extract ( $\mathrm{pH} 7.5$ ), $10 \%$ of the resulted broth was inoculated and incubated at $37^{\circ} \mathrm{C}$ for 3 days. The resulted broth was then spread on a feather meal agar plate (FMA) (FMB $+1.5 \%$ agar) and incubated at $37^{\circ} \mathrm{C}$ for 3 days. The colonies with clear zone (indicating those with feather hydrolyzing ability) on FMA were selected and inoculated into a fresh FMA. After 3 days incubation at $37^{\circ} \mathrm{C}$, the colony with highest feather hydrolyzing ability was picked up, re-activated in TSB (Tryptic soy broth) and subjected to identification. The isolated strain was stored at $-80^{\circ} \mathrm{C}$ in TSB with $20 \%$ (v/v) glycerol for the further study.

\section{Bacterial Identification}

API identification kits were used for the identification. Bacterial isolate was cultivated on nutrient agar (NA) plates at $37^{\circ} \mathrm{C}$ for 3 days. The colony was re-suspended in $2 \mathrm{~mL}$ of sterile distilled water and inoculated on $50 \mathrm{CHB}$ and $20 \mathrm{E}$ API strips (BioMérieux, France) according to manufacturer's instruction. After $16,24,40$ and $48 \mathrm{~h}$ incubation at $37^{\circ} \mathrm{C}$, the strips were removed and compared with API identification index and database.

The sequence of 16s rDNA of isolated strain was determined after genomic DNA extraction and PCR amplification as described by Thys et al. [25]. Comparison of the sequence with homologous strains in GenBank was performed using Basic Local Alignment Search Tool (BLAST). The phylogenetic tree was inferred from BLAST at National Center for Biotechnology Information (NCBI).

\section{Production of Keratinase}

To optimize medium composition for the production of keratinase, the inoculum, $1 \mathrm{~mL}$ of isolated strain in TSB with $20 \%$ (v/v) glycerol from $-80^{\circ} \mathrm{C}$ was added to $10 \mathrm{~mL}$ of TSB and incubated at $37^{\circ} \mathrm{C}$ overnight $\left(10^{8} \mathrm{CFU} / \mathrm{mL}\right)$. One $\mathrm{mL}$ of the activated isolated strain was transferred to $100 \mathrm{~mL}$ various media (FMB with various amounts of carbon or nitrogen sources) in a $250 \mathrm{~mL}$ flask. The isolated strain in these media was incubated under aerobic conditions at $37^{\circ} \mathrm{C}$ with $150 \mathrm{rpm}$ shaking. The viable cell counts $(\mathrm{CFU} / \mathrm{mL})$, keratinase activity and $\mathrm{pH}$ were measured during incubation. The optimal medium was employed for the production of keratinase.

\section{Purification of Keratinase}

The cultured broths were filtered through glass wool to remove the un-degraded feathers and then through a $0.45-\mu \mathrm{m}$ sterilized membrane (Gelman Sciences, Ann Arbor, MI) to remove bacterial cells. After being concentrated by membrane ultrafiltration (cutoff: 5,000) with an Amicon ultrafiltration system (Amicon Div., W. R. Grace and Co., Beverly, MA, USA) and dialyzed against a buffer containing $50 \mathrm{mM}$ potassium phosphate buffer ( $\mathrm{pH}$ 6.0, buffer A) overnight, the crude keratinase was chromatographed on a CM sepharose Fast Flow $(2.6 \times 30 \mathrm{~cm})$ which was equilibrated with buffer A. The proteins were eluted by $500 \mathrm{~mL}$ of buffer A with a linear gradient of 0.0 to $0.5 \mathrm{M} \mathrm{NaCl}$ at a flow rate of $0.5 \mathrm{~mL} / \mathrm{min}$. Fractions with keratinase activity were collected and subjected to Sephadex G-75 chromatography $(1.6 \times 70 \mathrm{~cm})$. The enzymes were eluted with a buffer containing $25 \mathrm{mM}$ potassium phosphate, $100 \mathrm{mM} \mathrm{NaCl}$ ( $\mathrm{pH} 7.5$, buffer B) at a flow rate of $0.5 \mathrm{~mL} / \mathrm{min}$. Eluted enzymes were collected at $4^{\circ} \mathrm{C}$ with 2.0 $\mathrm{mL} /$ tube. Fractions with keratinase activity were pooled and concentrated using an Amicon ultra-filtration system with Diaflo ultrafilters (cutoff: 10,000, Amicon Div., W. R. Grace and Co., Beverly, MA, USA) at $4^{\circ} \mathrm{C}$.

\section{Assay of Keratinase Activity}

Keratinase activity was determined by measuring the hydrolysis ability on azokeratin according to Sangali and Brandelli [22]. Azokeratin was prepared as described by Riffel et al. [19]. Briefly, $200 \mu \mathrm{L}$ of enzyme extract was added to 800 $\mu \mathrm{L}$ of azokeratin $(5 \mathrm{mg} / \mathrm{mL})$ in $50 \mathrm{mM}$ phosphate buffer $(\mathrm{pH}$ 7.5). After $60 \mathrm{~min}$ reaction at $50^{\circ} \mathrm{C}$, equal volume of $15 \%$ trichloroacetic acid (TCA) solution was added to stop the reaction. Absorbance at $450 \mathrm{~nm}$ was then measured after 5 min centrifugation at $10,000 \times \mathrm{g}$. One unit of activity was defined as the amount of keratinase that caused an increase in absorbance of 0.01 at $450 \mathrm{~nm}$ within $60 \mathrm{~min}$ reaction at $50^{\circ} \mathrm{C}$.

\section{Determination of Protein Concentration}

Protein concentrations were determined by dye binding method [4] using bovine serum albumin as standard.

\section{Sodium Dodecyl Sulfate Polyacrylamide Gel Electrophoresis (SDS-PAGE)}

The SDS-PAGE analysis was carried out in a $12.5 \%$ polyacrylamide gel according to Laemmli [12]. Ten $\mu \mathrm{g}$ of enzyme samples was applied on each cell of gel. After electrophoretic running, gels were stained with Coomassie blue R-250 [17]. Low molecular weight calibration kit (GE Healthcare BioSciences Corp., MA, USA) was used as markers [Phosphorylase b subunit (97 kDa), bovine serum albumin $(67 \mathrm{kDa})$, ovalbumin (43 kDa), carbonic anhydrase (29 kDa), soybean inhibitor (20.1 kDa), and $\alpha$-lactalbumin $(14 \mathrm{kDa})]$.

\section{Isoelectric Point (pI)}

The $\mathrm{p} I$ of purified enzymes were measured using isoelectric focusing (IEF) on a Pharmacia Ampholine PAG plate (Multiphor II electrophoresis unit, GE Healthcare BioSciences Corp., MA, USA) (pH 3.5-9.5) and compared with standards from an IEF calibration kit according to the manufacturer's instruction. Trypsinogen (9.30), lentil lectin basic subunit (8.65), lentil lectin middle subunit (8.45), lentil lectin acidic subunit (8.15), myoglobin basic subunit (7.35), myoglobin acidic subunit (6.85), human carbonic anhydrase B (6.55), bovine carbonic anhydrase B (5.85), $\beta$-lactoglobulin A (5.20), soybean trypsin inhibitor (4.55) and amyloglucosidase (3.50) 
were used as markers (GE Healthcare BioSciences Corp., MA, USA).

\section{N-terminal Amino Acid Sequence Analysis}

Purified keratinases were subjected to SDS-PAGE analysis and then electro-transferred onto polyvinylidene difluoride membrane (PVDF). Proteins were stained with Coomassie blue R-250 after electrophoresis. N-terminal amino acid sequences were analyzed by Edman degradation [7] after being electro-transferred onto PVDF.

\section{Effects of $\mathbf{p H}$ and Temperature}

The effects of $\mathrm{pH}$ and temperature on keratinase activity were determined using azokeratin as substrate. The optimal $\mathrm{pH}$ was determined by measuring the activity of purified keratinases at $\mathrm{pH} 3.0-11.0 \mathrm{pH} 3.0-7.0$ using $20 \mathrm{mM}$ citrate buffer, $\mathrm{pH}$ 6.0-9.0 using $20 \mathrm{mM}$ sodium phosphate buffer, $\mathrm{pH}$ 8.0-11.0 using $20 \mathrm{mM}$ sodium carbonate buffer), while the optimal temperature of purified keratinases in $20 \mathrm{mM}$ sodium phosphate buffer $(\mathrm{pH} 7.5)$ was measured at temperatures from 10 to $90^{\circ} \mathrm{C}$ according to Sangali and Brandelli [22].

The $\mathrm{pH}$ stability was determined by incubating keratinases in various buffers with $\mathrm{pH} 3.0-11.0$ (pH 3.0-7.0 using $20 \mathrm{mM}$ citrate buffer, $\mathrm{pH}$ 6.0-9.0 using $20 \mathrm{mM}$ sodium phosphate buffer, $\mathrm{pH}$ 8.0-11.0 using $20 \mathrm{mM}$ sodium carbonate buffer) at $25^{\circ} \mathrm{C}$ for $60 \mathrm{~min}$. The residual activity was determined according to Sangali and Brandelli [22].

The thermal stability was determined by incubating keratinases in $20 \mathrm{mM}$ sodium phosphate buffer ( $\mathrm{pH} \mathrm{7.5)}$ at temperatures from $10^{\circ}$ to $90^{\circ} \mathrm{C}$ for $60 \mathrm{~min}$. The residual activity was then determined according to Sangali and Brandelli [22].

\section{Effects of Metal Ion, Reducing Agent or Inhibitor}

Purified keratinases in $20 \mathrm{mM}$ Tris- $\mathrm{HCl}$ buffer $(\mathrm{pH}$ 7.5) with metal ions $\left(\mathrm{Li}^{+}, \mathrm{Ba}^{2+}, \mathrm{Ca}^{2+}, \mathrm{Cd}^{2+}, \mathrm{Co}^{2+}, \mathrm{Cu}^{2+}, \mathrm{Fe}^{2+}, \mathrm{Hg}^{2+}\right.$, $\mathrm{Ni}^{2+}, \mathrm{Zn}^{2+}, \mathrm{Fe}^{3+}$ ), reducing (thiol) agents such as dithiothreitol (DTT), glutathione (GSH), $\beta$-mercaptoethanol ( $\beta$-Me) and other reagents or inhibitors such as ethylene diamine tetraacetic acid (EDTA), N-ethylmaleimide (NEM), $p$-chloromercuribenzoate ( $p \mathrm{CMB}$ ), phenylmethyl sulfonyl fluoride (PMSF) and $\mathrm{N}$-toylL-lysine chloromethyl ketone (TLCK), etc. were incubated at $25^{\circ} \mathrm{C}$ for $30 \mathrm{~min}$. The residual activity was measured according to Sangali and Brandelli [22].

\section{Statistical Analysis}

Duncan's multiple range tests was employed to determine the significance of difference among treatments. For each treatment, 3 measurements were used for calculation. Values were considered to be significantly different when $\mathrm{p}<0.05$.

\section{RESULTS AND DISCUSSION}

\section{Screening and Identification of Keratinase-Producing Bacteria}

The keratinase-producing bacteria, survived in $1.0 \%$ of
Table 1. Effects of extra nitrogen and carbon sources on the production of keratinase from Bacillus licheniformis YJ4.

\begin{tabular}{lc}
\hline Media & Keratinase (units/mL) \\
\hline Control $^{\#}$ & $80 \pm 4$ \\
Casein* & $50 \pm 2$ \\
Glucose* & $27 \pm 3$ \\
Rice husk* & $124 \pm 2$ \\
Peptone* & $33 \pm 2$ \\
Soytone* & $30 \pm 4$ \\
Soya meal* & $55 \pm 3$ \\
Starch* & $3 \pm 1$ \\
Surcose* & $30 \pm 2$ \\
Tryptone* & $20 \pm 4$ \\
\hline
\end{tabular}

${ }^{\#}$ Control: cultivated in FMB (1.0\% feather meal, $0.05 \%$ of $\mathrm{NH}_{4} \mathrm{Cl}$ and $\mathrm{NaCl}, 0.04 \% \mathrm{~K}_{2} \mathrm{HPO}_{4}, 0.03 \% \mathrm{KH}_{2} \mathrm{PO}_{4}, 0.01 \%$ of $\mathrm{MgCl}_{2}$ and yeast extract, $\mathrm{pH}$ 7.5).

*Cultivated in FMB with $0.1 \%$ of extra ingredient after $72 \mathrm{~h}$ incubation at $37^{\circ} \mathrm{C}$

feather meal broth after 7 days incubation at $37^{\circ} \mathrm{C}$, were isolated from feather dunghill. After the strains were transferred to FMA, only 6 colonies with feather degrading abilities were observed from the total 50 colonies (data not shown). Strain with the highest hydrolytic activity was subjected to identification.

According to the bacterial identification kit (ABI $50 \mathrm{CHB}$ and $\mathrm{ABI} 20 \mathrm{E}$ ) and 16s rDNA sequencing (data not shown), this strain was identified as Bacillus licheniformis YJ4, being a catalase-positive, oxidase-negative, endospore-forming, and Gram-positive bacterium. The alignment of $16 \mathrm{~s}$ rDNA by BLAST from GenBank indicated almost $99.6 \%$ sequence similarity with that from Bacillus licheniformis N8 (DQ350834) and $99.0 \%$ similarity with that from Bacillus sp. DCA-X (DQ305286). Keratinases from Bacillus species have long been studied and found that they could hydrolyze feathers [13, $15]$.

\section{Conditions for the Growth of Isolated Bacillus licheniformis YJ4}

Among the extra nitrogen or carbon sources used, high level of keratinase was obtained when it was grown in FMB containing $0.1 \%$ rice husk after $72 \mathrm{~h}$ incubation at $37^{\circ} \mathrm{C}$. As shown in Table 1, the other extra ingredients actually decreased keratinase production by Bacillus licheniformis. In order to optimize the concentration of rice husk on the production of keratinase, 0.05 to $1.0 \%(\mathrm{w} / \mathrm{v})$ of rice husk was added to FMB. Among various rice husk contents in FMB broth, keratinase increased significantly on medium with $0.1 \%$ $(\mathrm{w} / \mathrm{v})$ rich husk after $72 \mathrm{~h}$ incubation at $37^{\circ} \mathrm{C}(124 \mathrm{units} / \mathrm{mL}$, $\mathrm{p}<0.05)$ (Fig. 1(a)). Significant improvement in yield of keratinase was observed on the medium with extra $0.5 \%(\mathrm{w} / \mathrm{v})$ 


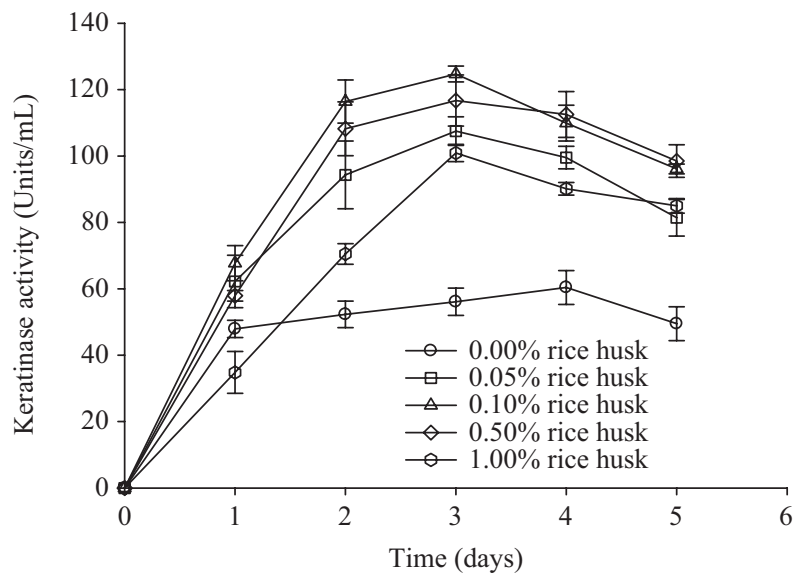

(a)

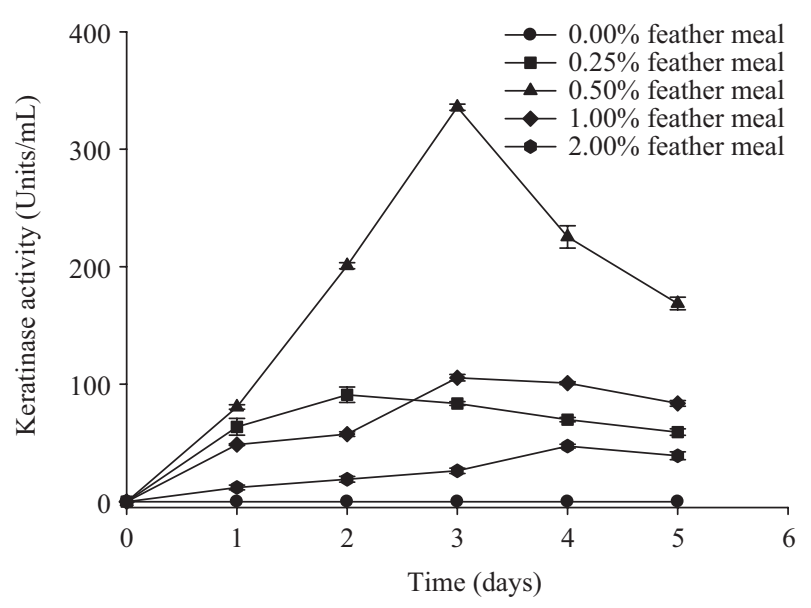

(b)

Fig. 1. Effect of rice husk (a) and feather meal content (b) on keratinase production from Bacillus licheniformis YJ4 during 5 days incubation at $37^{\circ} \mathrm{C}$ (A: Cultivated in FMB broth $(1.0 \%$ feather meal, $0.05 \%$ of $\mathrm{NH}_{4} \mathrm{Cl}$ and $\mathrm{NaCl}, 0.04 \% \quad \mathrm{~K}_{2} \mathrm{HPO}_{4}, 0.03 \% \quad \mathrm{KH}_{2} \mathrm{PO}_{4}$, $0.01 \%$ of $\mathrm{MgCl}_{2}$ and yeast extract; $\mathrm{pH} 7.5$ ) with various rice husk contents; B: Cultivated in various feather meal contents of FMB broth with $0.1 \%$ rice husk).

feather meal (348 units/mL) after $72 \mathrm{~h}$ incubation at $37^{\circ} \mathrm{C}$ (Fig. 1(b)). Medium containing $0.5 \%$ feather meal, $0.1 \%$ rice husk, $0.05 \%$ of $\mathrm{NH}_{4} \mathrm{Cl}$ and $\mathrm{NaCl}, 0.04 \% \mathrm{~K}_{2} \mathrm{HPO}_{4}, 0.03 \%$ $\mathrm{KH}_{2} \mathrm{PO}_{4}$, and $0.01 \%$ of $\mathrm{MgCl}_{2}$ and yeast extract ( $\mathrm{pH} 7.5$ ) was, therefore, used for further studies.

The yield of keratinase from this strain was influenced by physiological and natural substrate, i.e. rice husk. It was also related to the growth of the microbial strain. From the data obtained in this study, the soytone, tryptone or peptone nutrients could be replaced by rice husk and feather, which are by-products from crop and poultry industries, and could also obtain maximum keratinase production. The use of these alternative low cost nutrients will substantially reduce the production cost for this protease and further benefit the feather industry.

As shown in Fig. 2, after $12 \mathrm{~h}$ incubation, the culture en-

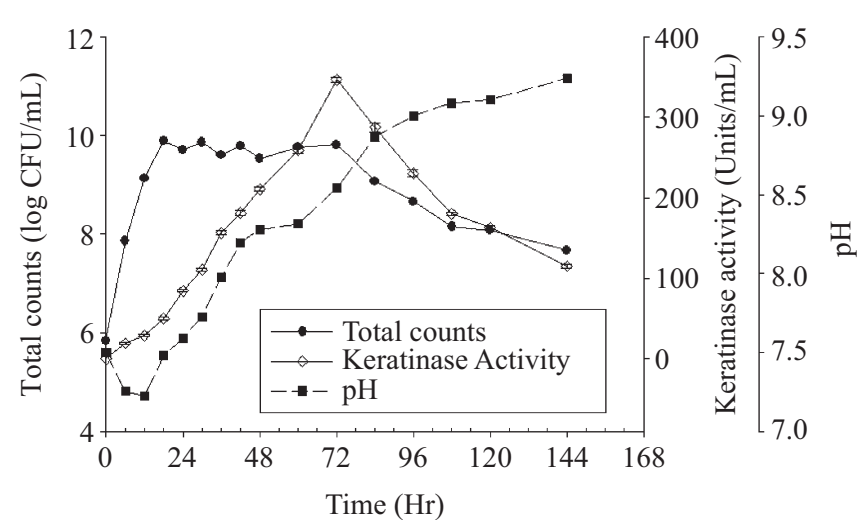

Fig. 2. Changes in total count, keratinase activity and $\mathrm{pH}$ of Bacillus licheniformis YJ4 during 6 days incubation at $37^{\circ} \mathrm{C}$.

tered stationary phase and keratinase production was greatly increased, with maximum of $350 \mathrm{U} / \mathrm{mL}$ being obtained at $72 \mathrm{~h}$. After $72 \mathrm{~h}$, both bacterial count and keratinase activity were declined, while the broth of $\mathrm{pH}$ continuously increased up to 9.24. This phenomenon suggested that the maximum proteases production was at late stationary phase, which was similar to that obtained by Altalo and Gashe [1]. These results also corresponded with previous study indicating that neutral or alkaline cultivation were suitable for keratinase production [23]. Therefore, broth of Bacillus licheniformis YJ4 after $72 \mathrm{~h}$ incubation at $37^{\circ} \mathrm{C}$ was collected for further purification and characterization of keratinases.

\section{Purification of Keratinases}

Keratinases were purified by ultrafiltration, CM sepharose Fast Flow ion-exchange and Sephadex G-75 chromatographs (Table 2). A specific activity of 800 units/mg was obtained after passing through a $0.45-\mu \mathrm{m}$ membrane. Two peaks with keratinase activity on CM Sepharose Fast Flow chromatography were observed and designated as keratinase I and II, respectively (Fig. 3). Since some very minor contamination was still observed at this stage, the resulted samples were, therefore, further passed through Sephadex G-75 chromatography (Fig. 4). Both keratinases were purified to electrophoretical homogeneity with specific activity of 876 and 1,060 units/mg and purification fold of 1.96 and 2.37, respectively (Table 2). Although some studies indicated that using affinity chromatography or hydrophobic interaction chromatography could increase the yield and recovery of keratinase [3, 9], they did not affect the yield in this study (data not shown).

\section{Molecular Mass (M), Isoelectric Point $(p I)$ and N-terminal Amino Acid Sequence of Keratinases}

According to Sephadex G-75 chromatography and SDSPAGE (Fig. 5), both purified keratinase I and II, with molecular masses $(M)$ of 35.5 and $32.8 \mathrm{kDa}$, and Isoelectric point $(\mathrm{p} I)$ of 6.63 and 6.50 (data not shown), respectively, were monomer. The $M$ of both keratinases were similar to those 
Table 2. Summary of the purification of keratinase from Bacillus licheniformis YJ4.

\begin{tabular}{lccccc}
\hline Procedures & Total Protein (mg) & Total Activity (unit) & $\begin{array}{c}\text { Specific Activity } \\
\text { (unit/mg) }\end{array}$ & Recovery (\%) & Purification (fold) \\
\hline Crude enzyme & 186 & 83,162 & 447 & 100.00 & 1.00 \\
Ultra-filtration & 129 & 79,800 & 619 & 95.96 & 1.38 \\
CM Sepharose & & & & 3.12 & 1.92 \\
Keratinase I & 3.03 & 2,595 & 856 & 11.83 & 2.27 \\
Keratinase II & 9.7 & 9,840 & 1,014 & & \\
Sephadex G-75 & & & & 2.93 & 1.96 \\
Keratinase I & 2.78 & 2,436 & 876 & 11.53 & 2.37 \\
Keratinase II & 9.05 & 9,592 & 1,060 & & \\
\hline
\end{tabular}

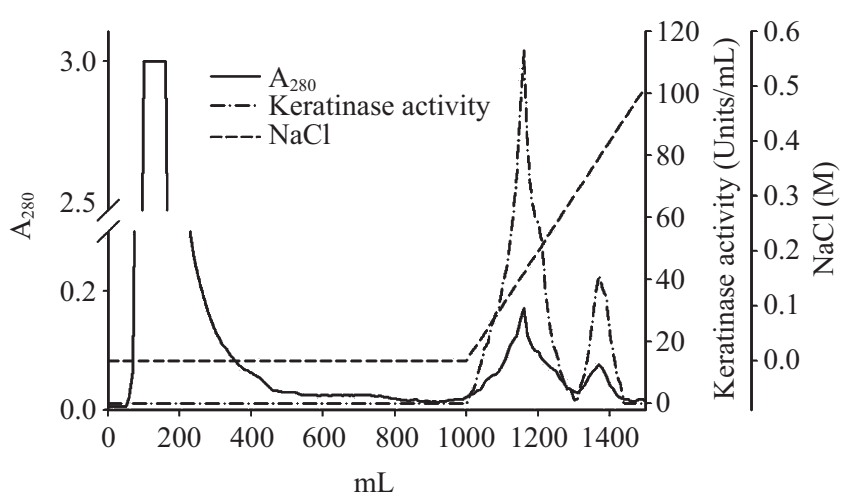

Fig. 3. Chromatogram of keratinases on CM Sepharose Fast Flow (The crude enzyme solution was concentrated with $50 \mathrm{mM}$ potassium phosphate buffer, pH 6.0 (buffer A) using an Amicon ultrafiltration. The resulted sample was applied onto CM Sepharose Fast Flow which was previously equilibrated with buffer A. After being washed with buffer $A$, the column was then eluted using a linear gradient of 0 to $0.5 \mathrm{M} \mathrm{NaCl}$ in buffer $\mathrm{A}$. Fractions of $5 \mathrm{~mL}$ were collected at a flow rate of $0.5 \mathrm{~mL} / \mathrm{min}$. —, $\mathrm{A} \mathrm{A}_{280} ;---$, $\mathrm{NaCl}$; - • - , keratinase activity).

from Bacillus licheniformis PWD-1, Strepomyces pactum DSM 40530, and Doratomyces microsporus (30-35 kDa) [3, 9, 15].

The N-terminal amino acid sequence of keratinase II was DINGGGAT, which was completely the same as that of subtilisins. Accordingly, it was considered to be the subtilisin family of serine protease [1]. On the contrary, the N-terminal amino acid sequence of keratinase I was AQTVPYGI, which was completely different from those of other Bacillus strains in database of NCBI.

\section{Effects of pH and Temperature}

Both keratinases had similar optimal $\mathrm{pH}$ and temperature at 9.0 and $60^{\circ} \mathrm{C}$, respectively, and were stable at $\mathrm{pH} 6.0 \sim 10.0$ and $10 \sim 50^{\circ} \mathrm{C}$ (Figs. 6 and 7). Keratinases from bacteria, actinomycetes and fungi had optimal $\mathrm{pH}$ from neutral to alkaline [2, $8,11,25]$. The optimal temperatures of keratinolytic proteases from other Baciilus were between 50 and $60^{\circ} \mathrm{C}$ [21, 24]. According to $\mathrm{pH}$ and thermal stability of both purified keratinase I and II, they were similar with those obtained from other species $[8,10,29]$.

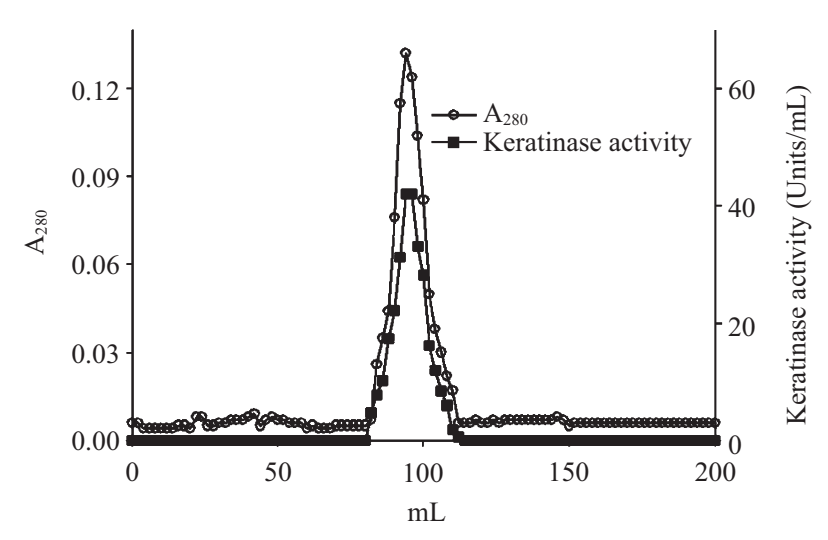

(a)

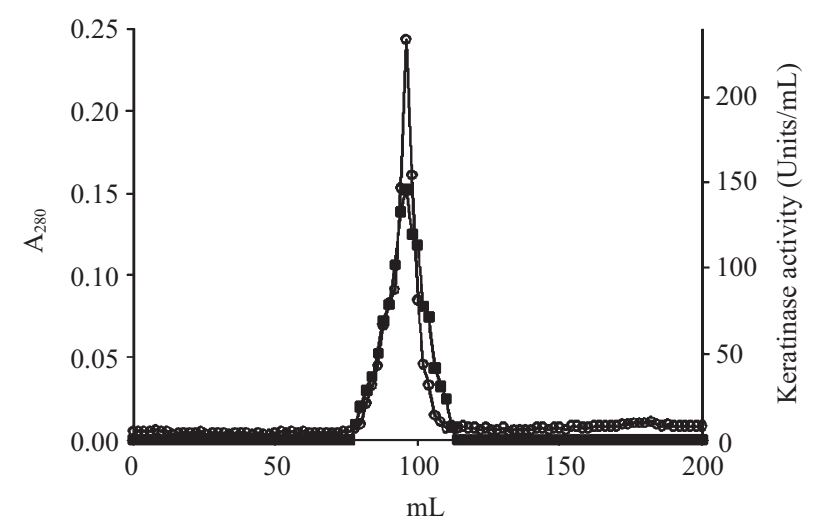

(b)

Fig. 4. Elution profile of keratinase I (a) and II (b) on a Sephadex G-75 chromatography. Elution was performed using buffer $B$ at a flow rate of $0.5 \mathrm{~mL} / \mathrm{min}$. (—) $\mathrm{A}_{280}$; (-• - ) keratinase activity.

\section{Effects of Metal Ions, Reducing Agents and Inhibitors}

Keratinase I was moderately inhibited by $\mathrm{Ca}^{2+}, \mathrm{Cd}^{2+}, \mathrm{Co}^{2+}$, $\mathrm{Ni}^{2+}$, TLCK and EDTA, and highly inhibited by $\mathrm{Cu}^{2+}, \mathrm{Fe}^{2+}$, $\mathrm{Hg}^{2+}, \mathrm{Zn}^{2+}, \mathrm{Fe}^{3+}, \mathrm{NEM}$ and $p$ CMB. It was activated by $\mathrm{Li}^{+}$, DTT, GSH and $\beta$-Me (Table 3). Keratinase II was moderately inhibited by $\mathrm{Cd}^{2+}, \mathrm{Co}^{2+}, \mathrm{Fe}^{2+}, \mathrm{Ni}^{2+}$, EDTA, NEM, $p \mathrm{CMB}$ and TLCK, and highly inhibited by $\mathrm{Cu}^{2+}, \mathrm{Hg}^{2+}, \mathrm{Zn}^{2+}, \mathrm{Fe}^{3+}$ and PMSF. However, it was activated by DTT, GSH and $\beta-\mathrm{Me}$ (Table 3). 


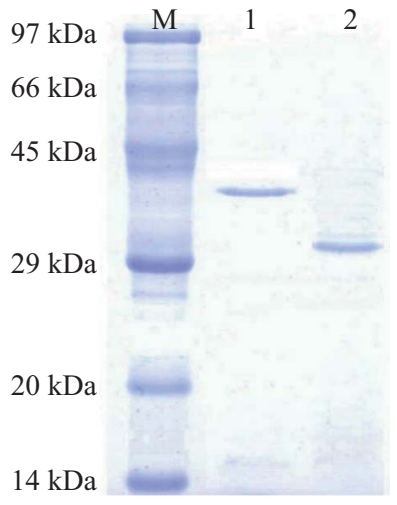

Fig. 5. SDS-PAGE of keratinase I and II (After electrophoresis, the proteins were stained with Coomassie blue R-250. Lane 1: keratinase I; Lane 2: keratinase II; Lane M: Low molecular weight proteins marker, 14 97 kDa).

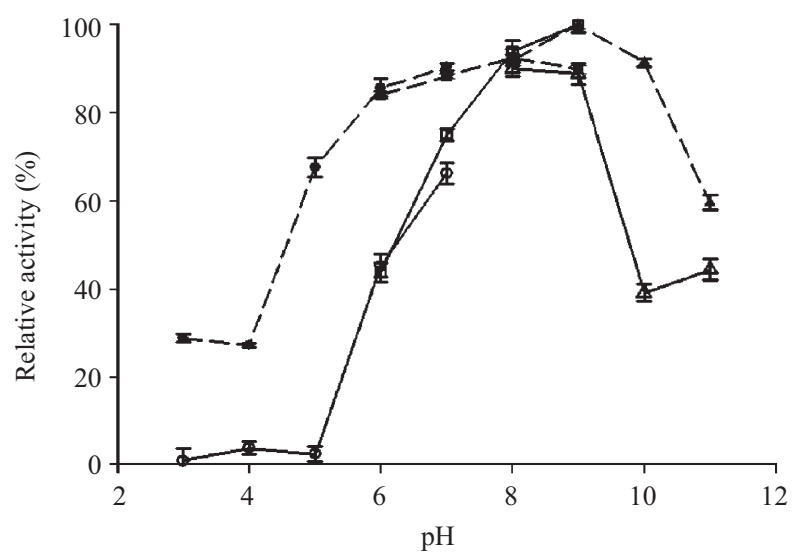

(a)

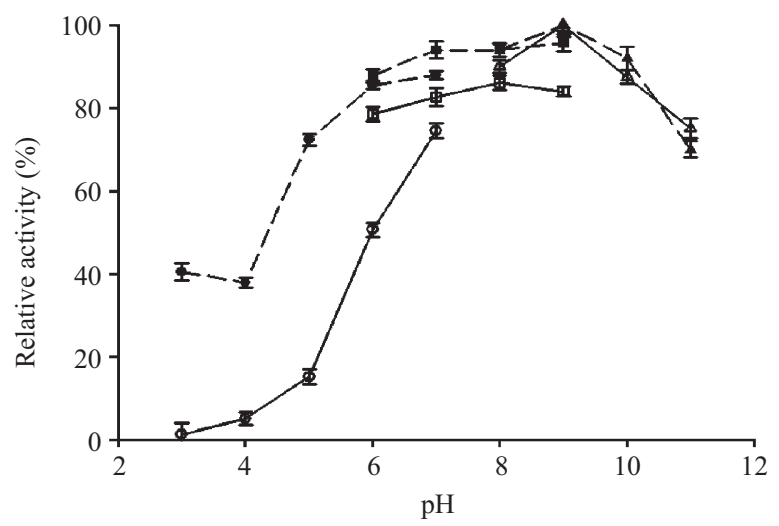

(b)

Fig. 6. Effect of pH on the activity of purified keratinase I (a) and II (b) $(---$, stability; —_, optimal pH; $\bullet$ and $\circ$, pH 3.0-7.0 in $20 \mathrm{mM}$ citrate buffer; $\square$ and $\square$, pH 6.0-9.0 in $20 \mathrm{mM}$ sodium phosphate buffer; $\Delta$ and $\Delta, \mathbf{p H}$ 8.0-11.0 in $20 \mathrm{mM}$ sodium carbonate buffer).

Many studies have used the reducing agents such as DTT, $\beta-\mathrm{ME}$ and reduced glutathione to enhance keratinase activity $[3,5,19]$. They also observed that reducing agents can de-

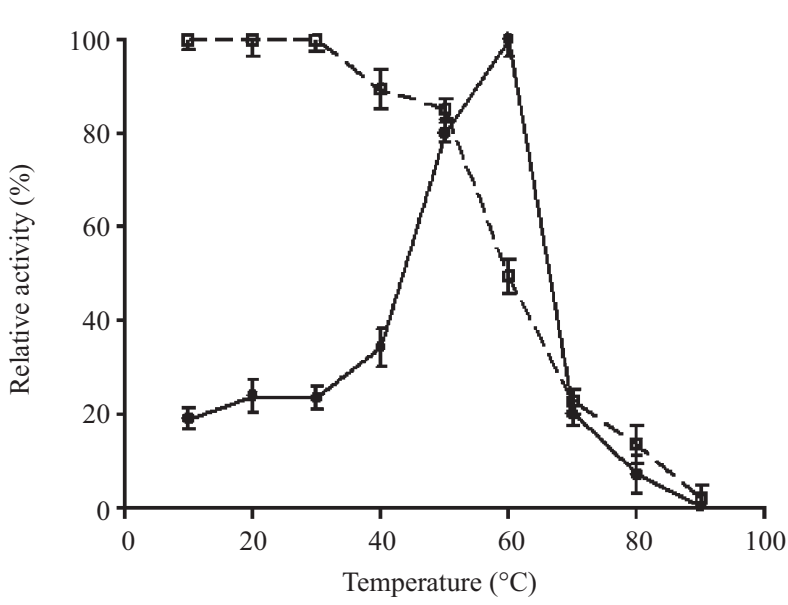

(a)

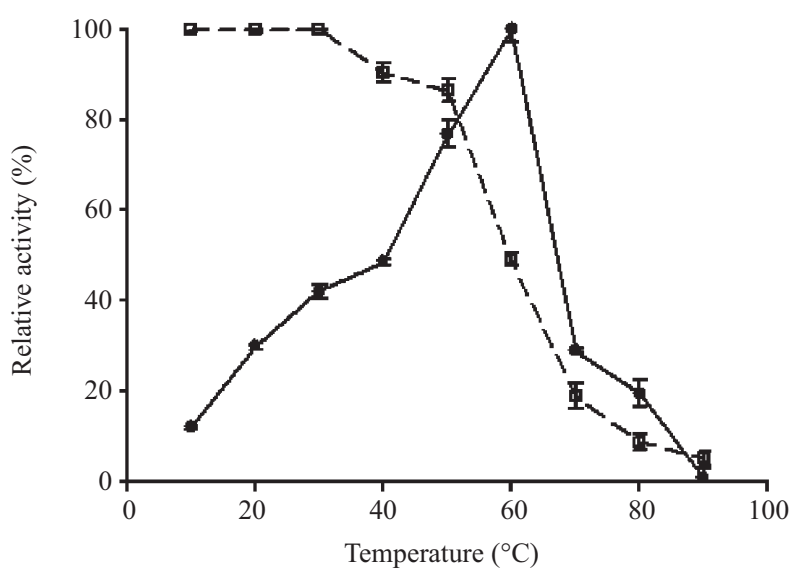

(b)

Fig. 7. Effect of temperature on the activity of purified keratinase $I$ (a) and II (b) (—•-, Optimal temperature; - - , thermal stability).

crease the disulfide bonds of keratin by sulfitolysis, and also make keratinase much easier access to substrate for keratinolysis $[6,14]$. In other cases, transition and heavy metals including $\mathrm{Hg}^{2+}[19,25], \mathrm{Zn}^{2+}[6,25], \mathrm{Cu}^{2+}[16,25]$ and $\mathrm{Co}^{2+}[6]$ inhibited keratinase activity.

Gupta and Ramnani [10] considered that most of keratinases belong to subtilisin group of proteases, because they possess serine or metallo catalytic center and have $\mathrm{pH}$ optima from neutral to alkaline. However, few keratinases were cysteine protease [18, 20, 21]. Rozs et al. [21] observed that a novel thiol protease from Bacillus licheniformis strain could be inhibited by $p \mathrm{CMB}$ and $\mathrm{Hg}^{2+}$. According to the data obtained in this study, the purified keratinase I (sensitivity to $\mathrm{NEM}$ and $p \mathrm{CMB}$, and moderately inhibited by metals such as $\mathrm{Hg}^{2+}$ and $\mathrm{Zn}^{2+}$ ) and keratinase II (highly inhibited by $\mathrm{Cu}^{2+}$, $\mathrm{Hg}^{2+}, \mathrm{Zn}^{2+}, \mathrm{Fe}^{3+}$ and PMSF) were considered to be cysteine and serine proteases, respectively.

In summary, the isolated Bacillus licheniformis YJ4, with high keratinolytic activity, could use the natural wastes, feather and rice husk, as substrates, and consequently lowered the cost for the production of keratinase. The produced kerati- 
Table 3. Effect of metal ions and chemicals on the activity of purified keratinase I and II.

\begin{tabular}{|c|c|c|c|c|c|c|}
\hline \multirow{4}{*}{ Metals } & \multicolumn{6}{|c|}{ Relative Activity (\%) } \\
\hline & \multicolumn{3}{|c|}{ Keratinase I } & \multicolumn{3}{|c|}{ Keratinase II } \\
\hline & \multicolumn{3}{|c|}{ Concentration (mM) } & \multicolumn{3}{|c|}{ Concentration $(\mathrm{mM})$} \\
\hline & 1.0 & 5.0 & 10.0 & 1.0 & 5.0 & 10.0 \\
\hline None & 100.0 & 100.0 & 100.0 & 100.0 & 100.0 & 100.0 \\
\hline $\mathrm{Li}^{+}$ & $115.3 \pm 2.9$ & $120.2 \pm 0.8$ & $102.0 \pm 1.6$ & $107.1 \pm 1.1$ & $101.2 \pm 0.6$ & $90.8 \pm 1.2$ \\
\hline $\mathrm{Ba}^{2+}$ & $95.8 \pm 0.7$ & $102.9 \pm 2.4$ & $90.2 \pm 0.1$ & $102.9 \pm 1.4$ & $102.1 \pm 1.3$ & $71.9 \pm 2.4$ \\
\hline $\mathrm{Ca}^{2+}$ & $87.3 \pm 2.4$ & $88.5 \pm 0.1$ & $78.4 \pm 1.6$ & $101.5 \pm 0.3$ & $102.4 \pm 1.2$ & $80.5 \pm 1.8$ \\
\hline $\mathrm{Cd}^{2+}$ & $105.1 \pm 3.5$ & $95.2 \pm 1.9$ & $70.6 \pm 2.0$ & $91.0 \pm 0.1$ & $85.1 \pm 2.4$ & $68.7 \pm 1,8$ \\
\hline $\mathrm{Co}^{2+}$ & $75.4 \pm 2.1$ & $84.6 \pm 0.2$ & $92.2 \pm 0.2$ & $86.2 \pm 1.1$ & $83.9 \pm 0.3$ & $61.3 \pm 1.0$ \\
\hline $\mathrm{Cu}^{2+}$ & $71.2 \pm 1.4$ & $68.3 \pm 2.4$ & $10.8 \pm 0.8$ & $77.2 \pm 2.4$ & $55.7 \pm 0.7$ & $34.6 \pm 0.7$ \\
\hline $\mathrm{Fe}^{2+}$ & $72.9 \pm 1.4$ & $59.6 \pm 0.1$ & $2.0 \pm 1.6$ & $88.1 \pm 1.4$ & $82.1 \pm 0.6$ & $50.8 \pm 2.7$ \\
\hline $\mathrm{Hg}^{2+}$ & $92.4 \pm 2.1$ & $48.1 \pm 2.7$ & $39.2 \pm 2.4$ & $36.5 \pm 0.3$ & $5.4 \pm 1.8$ & $1.0 \pm 0.3$ \\
\hline $\mathrm{Ni}^{2+}$ & $73.7 \pm 0.7$ & $73.1 \pm 3.1$ & $64.7 \pm 0.1$ & $80.1 \pm 1.3$ & $80.4 \pm 0.3$ & $58.7 \pm 1.6$ \\
\hline $\mathrm{Zn}^{2+}$ & $28.0 \pm 3.5$ & $2.8 \pm 0.8$ & $0.0 \pm 2.4$ & $104.5 \pm 1.0$ & $27.1 \pm 0.4$ & $3.9 \pm 0.4$ \\
\hline $\mathrm{Fe}^{3+}$ & $0.0 \pm 2.8$ & $0.0 \pm 2.4$ & $0.0 \pm 1.6$ & $101.0 \pm 1.1$ & $26.8 \pm 0.3$ & $1.0 \pm 0.1$ \\
\hline \multirow{2}{*}{ Chemicals } & \multicolumn{3}{|c|}{ Concentration (mM) } & \multicolumn{3}{|c|}{ Concentration $(\mathrm{mM})$} \\
\hline & 1.0 & 2.0 & 5.0 & 1.0 & 2.0 & 5.0 \\
\hline DTT & $143.4 \pm 4.6$ & $126.7 \pm .07$ & $133.0 \pm 1.3$ & $104.8 \pm 2.3$ & $100.5 \pm 0.1$ & $114.8 \pm 3.5$ \\
\hline EDTA & $94.3 \pm 0.1$ & $76.7 \pm .07$ & $72.3 \pm 0.5$ & $87.3 \pm 2.6$ & $83.2 \pm 0.2$ & $88.3 \pm 1.8$ \\
\hline GSH & $134.0 \pm 4.1$ & $117.2 \pm 2.8$ & $121.3 \pm 4.7$ & $103.2 \pm 2.5$ & $102.9 \pm 1.3$ & $113.0 \pm 0.1$ \\
\hline NEM & $79.3 \pm 1.5$ & $75.0 \pm 3.5$ & $45.7 \pm 4.3$ & $86.4 \pm 3.3$ & $87.2 \pm 0.2$ & $67.0 \pm 3.5$ \\
\hline$\beta-\mathrm{ME}$ & $115.1 \pm 1.5$ & $120.7 \pm 4.2$ & $134.0 \pm 1.7$ & $89.6 \pm 3.8$ & $107.5 \pm 1.3$ & $115.2 \pm 1.8$ \\
\hline$p \mathrm{CMB}$ & $77.7 \pm 0.8$ & $72.6 \pm 0.8$ & $50.0 \pm 4.8$ & $94.6 \pm 0.8$ & $91.5 \pm 0.9$ & $79.1 \pm 0.2$ \\
\hline PMSF & $106.6 \pm 3.8$ & $104.3 \pm 0.7$ & $104.3 \pm 1.7$ & $33.2 \pm 2.8$ & $38.8 \pm 0.9$ & $18.7 \pm 0.4$ \\
\hline TLCK & $74.5 \pm 2.3$ & $77.6 \pm 0.5$ & $83.0 \pm 4.8$ & $74.4 \pm 1.3$ & $79.5 \pm 3.4$ & $68.7 \pm 1.4$ \\
\hline
\end{tabular}

nase I and II were considered to be cysteine and serine proteases, respectively.

\section{REFERENCES}

1. Altalo, K. and Gashe, B., "Protease production by a thermophilic Bacillus species (P-001A) which degrades various kinds of fibrous proteins," Biotechnology Letters, Vol. 15, pp. 1151-1156 (1993).

2. Anbu, P., Gopinath, S. C. B., Hilda, A., Priya, T. L., and Annadurai, G., "Purification of keratinase from poultry farm isolate Scopulariopsis brevicaulis and statistical optimization of enzyme activity," Enzyme and Microbial Technology, Vol. 36, No. 5-6, pp. 639-647 (2005).

3. Bockle, B., Galunsky, B., and Muller, R., "Characterization of a keratinolytic serine proteinase from Streptomyces Pactum DSM 40530," Applied and Environmental Microbiology, Vol. 61, No. 10, pp. 3705-3710 (1995).

4. Bradford, M. M., "A rapid and sensitive method for the quantitation of microgram quantities of protein utilizing the principle of protein-dye binding," Analytical Biochemistry, Vol. 72, pp. 248-254 (1976).

5. Bressollier, P., Letourneau, F., Urdaci, M., and Verneuil, B., "Purification and characterization of a keratinolytic serine proteinase from Streptomyces albidoflavus," Applied and Environmental Microbiology, Vol. 65, No. 6, pp. 2570-2576 (1999).

6. Dozie, I., Okeke, C., and Unaeze, N., "A thermostable, alkaline-active, keratinolytic proteinase from Chrysosporium keratinophilum," World Journal of Microbiology \& Biotechnology, Vol. 10, No. 5, pp. 563-567 (1994).

7. Edman, P. and Begg, G., "A protein sequencer," European Journal of Biochemistry, Vol. 1, pp. 80-91 (1967).
8. Farag, A. M. and Hassan, M. A., "Purification, characterization and immobilization of a keratinase from Aspergillus oryzae," Enzyme and Microbial Technology, Vol. 34, No. 2, pp. 85-93 (2004).

9. Gradisar, H., Kern, S., and Friedrich, J., "Keratinase of Doratomyces microsporus," Applied Microbiology and Biotechnology, Vol. 53, No. 2, pp. 196-200 (2000).

10. Gupta, R. and Ramnani, P., "Microbial keratinases and their prospective applications: an overview," Applied Microbiology and Biotechnology, Vol. 70, No. 1, pp. 21-33 (2006).

11. Ignatova, Z., Gousterova, A., Spassov, G., and Nodkov, P., "Isolation and partial characterisation of extracellular keratinase from a wool degrading thermophilic actinomycete strain Thermoactinomyces candidus," Canadian Journal of Microbiology, Vol. 45, No. 3, pp. 217-222 (1999).

12. Laemmli, U. K., "Cleavage of structural proteins during the assembly of the head of bacteriophage T4," Nature, Vol. 227, No. 5259, pp. 680-685 (1970).

13. Lal, S., Rajak, R. C., and Hasija, S. K., "In vitro degradation of keratin by two species of Bacillus," The Journal of General and Applied Microbiology, Vol. 45, No. 6, pp. 283-287 (1999).

14. Lee, H., Suh, D. B., Hwang, J. H., and Suh, H. J., "Characterization of a keratinolytic metalloprotease from Bacillus sp. SCB-3," Applied Biochemistry and Biotechnology, Vol. 97, No. 2, pp. 123-133 (2002).

15. Lin, X., Lee, C. G., Casale, E. S., and Shih, J. C., "Purification and characterization of a keratinase from a feather-degrading Bacillus licheniformis Strain.," Applied and Environmental Microbiology, Vol. 58, No. 10, pp. 3271-3275 (1992).

16. Nam, G. W., Lee, D. W., Lee, H. S., Lee, N. J., Kim, B. C., Choe, E. A., Hwang, J. K., Suhartono, M. T., and Pyun, Y. R., "Native-feather degradation by Fervidobacterium islandicum AW-1, a newly isolated keratinase-producing thermophilic anaerobe," Archives of Microbiology, Vol. 
178, No. 6, pp. 538-547 (2002)

17. Neuhoff, V., Arold, N., Taube, D., and Ehrhardt, W., "Improved staining of proteins in polyacrylaminde gel including isoelectric focusing gels with clear background at nanogram sensitivity using coomassie brilliant blue G-250 and R-250," Electrophoresis, Vol. 9, No. 6, pp. 255-262 (1988).

18. Patel, B. K. and Jagannadham, M. V., "A high cysteine containing thiol proteinase from the latex of Ervatamia heyneana: purification and comparison with ervatamin B and C from Ervatamia coronaria," Journal of Agricultural and Food Chemistry, Vol. 51, No. 21, pp. 6326-6334 (2003).

19. Riffel, A., Lucas, F., Heeb, P., and Brandelli, A., "Characterization of a new keratinolytic bacterium that completely degrades native feather keratin," Archives of Microbiology, Vol. 179, No. 4, pp. 258-265 (2003).

20. Rivett, A., "Purification of a liver alkaline protease which degrades oxidatively modified glutamine synthetase.,"Journal of Biological Chemistry, Vol. 260, No. 23, pp. 12600-12606 (1985).

21. Rozs, M., Manczinger, L., Vagvolgyi, C., and Kevei, F., "Secretion of a trypsin-like thiol protease by a new keratinolytic strain of Bacillus licheniformis," FEMS Microbiology Letters, Vol. 205, No. 2, pp. 221-224 (2001).

22. Sangali, S. and Brandelli, A., "Feather keratin hydrolysis by a Vibrio sp. strain kr2," Journal of Applied Microbiology, Vol. 89, No. 5, pp. 735-743 (2000).
23. Suntornsuk, W. and Suntornsuk, L., "Feather degradation by Bacillus sp FK 46 in submerged cultivation," Bioresource Technology, Vol. 86, No. 3, pp. 239-243 (2003).

24. Suntornsuk, W., Tongjun, J., Onnim, P., Oyama, H., Ratanakanokchai, K., Kusamran, T., and Oda, K., "Purification and characterisation of keratinase from a thermotolerant feather-degrading bacterium," World Journal of Microbiology \& Biotechnology, Vol. 21, No. 6-7, pp. 1111-1117 (2005).

25. Thys, R. C. S., Lucas, F. S., Riffel, A., Heeb, P., and Brandelli, A., "Characterization of a protease of a feather-degrading Microbacterium species," Letters in Applied Microbiology, Vol. 39, No. 2, pp. 181-186 (2004).

26. Wang, X. and Parsons, C., "Effect of processing systems on protein quality of feather meal and hog hair meals," Poultry Science, Vol. 76, No. 3, pp. 491-496 (1997).

27. Williams, C., Lee, C., Garlich, J., and Shih, J., "Evaluation of a bacterial feather fermentation product, feather-lysate, as a feed protein," Poultry Science, Vol. 70, No. 1, pp. 85-94 (1991).

28. Williams, C. M., Richter, C. S., Mackenzie, J. M., and Shih, J. C., "Isolation, identification, and characterization of a feather-degrading bacterium," Applied and Environmental Microbiology, Vol. 56, No. 6, pp. 1509-1515 (1990).

29. Yin, L. J., Lee, J. H., and Jiang, S. T., "Isolation of a keratinase-producing bacterium and purification of its keratinase," Journal of Fish Society Taiwan, Vol. 33, No. 4, pp. 377-390 (2006). 